number of times that aurora was visible with the extent of country over which it was observed, and the numbers stand thus :--

$\begin{array}{lllr}\text { January } & \ldots & \ldots & 29 \cdot 7 \\ \text { February } & \ldots & \ldots & 42^{\circ} \cdot 5 \\ \text { March ... } & \ldots & \ldots & 35^{\circ} \cdot \\ \text { April } \ldots & \ldots & \ldots & 27 \cdot 5 \\ \text { May } \ldots & \ldots & \ldots & 4 \cdot 8 \\ \text { June } \ldots & \ldots & \ldots & 0 \cdot 0 \\ \text { July } \ldots & \ldots & \ldots & 0^{\circ} \cdot 5 \\ \text { August } & \ldots & \ldots & \mathbf{1} 2 \cdot 6 \\ \text { September } & \ldots & \ldots & 36 \cdot 0 \\ \text { October } & \ldots & \ldots & 49 \cdot 4 \\ \text { November } & \ldots & \ldots & 32 \cdot 4 \\ \text { December } & \ldots & \ldots & 28 \cdot 8\end{array}$

It will thus be seen that October and February are precisely the two months. when brilliant auroras are most likely to be seen; and that of these two maxima of the annual cycle October has rather the advantage.

The lightning return, prepared on the same principle, is not uninstructive to be compared against the aurora; for, though both in its aerrial altitude and actual numerical returns, lightning may be the very opposite of aurora, yet it exhibits a tendency to a similar double maximum in the course of the year; and not a few of the lightning storms of that second, or winter maximum, are locomotive "meteors," travelling from S.W. to N.E., and having undoubtedly a very wide-spread earth-influence and physical signification. The actual numbers are these :-

\begin{tabular}{|c|c|c|c|}
\hline January & $\ldots$ & $\ldots$ & $24^{\circ} \mathrm{O}$ \\
\hline February & $\ldots$ & $\ldots$ & 144 \\
\hline March ... & $\ldots$. & $\ldots$ & $7 \circ 0$ \\
\hline April ... & $\ldots$ & $\ldots$ & 154 \\
\hline May ... & $\ldots$ & $\ldots$ & 374 \\
\hline Jume & $\ldots$ & $\ldots$ & 48.0 \\
\hline July $\quad .$. & $\ldots$ & $\ldots$ & 53.2 \\
\hline August & $\ldots$ & $\ldots$ & $38 \cdot 4$ \\
\hline September & $\ldots$ & $\ldots$ & $22 \cdot 4$ \\
\hline October & $\ldots$ & $\ldots$ & $20 \cdot 8$ \\
\hline November & $\ldots$ & $\ldots$ & $15^{\circ} \mathrm{O}$ \\
\hline December & $\ldots$ & $\ldots$ & $15^{\circ} \mathrm{O}$ \\
\hline
\end{tabular}

15, Royal Terrace, Edinburgh, Feb. 10

C. Piazzi Smyth

\section{The Aurora of February 4}

I wILL not attempt to describe the wonderfully gorgeous display of aurora which I witnessed on Sunday night, February 4. I merely wish to mention a circumstance connected with it which may have some interest. I was watching for the zodiacal light at about 5.30 , and, having perceived faint traces of it, I presently saw some peculiar red clouds a little above it ; from their rapid change of form I soon became aware that this was the light of an aurora. From that time, and from that spot, it spread rapidly; a bright white arch extending high overhead from W. to $E$., while a segment of blue sky stretched low down in the

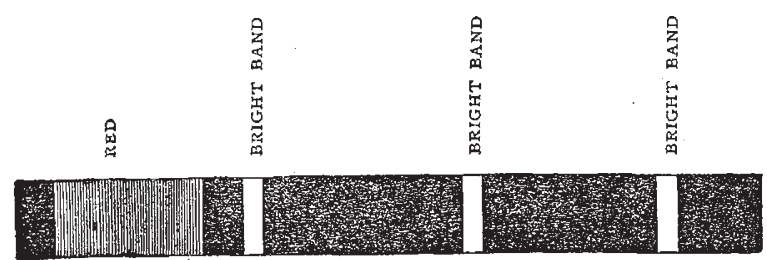

S.E. in the magnetic meridian, the space between being filled with brilliant colours. Shortly after this a radiating point became very striking, not in the zenith, but at one-third the distance from the Pleiades to Capella; and then the folds of gorgeous light-red, white, and faint green, interspersed with dark shading, spread from it, like a canopy, down on all sides except in the N.W. I never witnessed or read of such a display in these latitudes. With one of Browning's small star spectroscopes the spectrum consisted of a small portion of brilliant red, then a bright band rather close to it, and then two others bayond; the two latter being rather nearer together than the first and second; that at the more refrangible end being the fainrest, and that near the red the strongest. I enclose a sketch showing the spectrum, the slit being wide open.

The maximum display was between 6.45 and 7 P.M ; at 7.15 it was fading rapidly. Clouds covered the sky at 7.30 , and some smart electric showers fell; still I could see that the display was going on; and at II P.M., in spite of dense clouds, the light was sufficient to enable me to read large print.

Stretton Rectory, Hereford, Feb. 6 HENRY COOPER KEY

ON Sunday evening $4^{\text {th }}$ inst., a beautiful display of aurora was observed here (lat. $5 \mathrm{r}^{\circ} 26^{\prime} \mathrm{o}^{\prime \prime} \mathrm{N}$., long. $\mathrm{O}^{\circ} 2 \mathrm{o}^{\prime} 53^{\prime \prime} \mathrm{W}$.). My attention was first directed to it at 6h. 4m. (G.M.T.) at which time there was a fiery glow over a considerable portion of the southern sky, much resembling the reflection of a distant conflagration. Shortly after, an almost complete auroral arch, of faint orange red light, similar to that at first observed, was noticed, extending from $E$, above and partly embracing $\delta$, $\epsilon$, and $\zeta$ Orionis, to W., its altitude (by estimation) at the centre being about $40^{\circ}$, and its extent something like $120^{\circ}$. For a short time this glow was most intense in S.S.E. at a great altitude, but the display attained its greatest intensity about $6 \mathrm{~h}$. $15 \mathrm{~m}$., when a number of rays or streamers of whitish blue and orange red light appeared as if radiating from a point near $\delta, \alpha$, and $k$ Persei. At $6 \mathrm{~h} .20 \mathrm{~m}$. nothing was observed but a widely diffused fiery glow, which must have continued more or less during the whole evening, as it was again observed by me at $8 \mathrm{~h} .25 \mathrm{~m}$.

Fulwell, near Twickenham JOHN JAMES HAII

THERE was a fine display of the above phenomenon here on Sunday night, February 4. At five o'clock a muddy undefined redness made its appearance in the N.E. and W., especially in the former, which continued for some time without any very marked change. Towards half-past six the redness became more concentrated, gradually brightened, and finally became of a most intense brilliancy-indeed, so much so that it fairly baffles description, the landscape and the countenances of those standing near being visibly tinged. Streamers soon began to form, and shoot gradually upwards from the horizon in all directions from N.E. by S. to W., some intensely red, some very white, while others were of a greenish hue. The red and white being very brilliant, were finely intermingled, especially in a N.E. direction, while a muddy green prevailed chiefly in the S., and a reddish tinge in the W. By seven o'clock that rare phenomenon, a corona, was formed overhead, assuming a variety of shapes. The most curious part of the display (as far as my experience goes) was the entire absence up to this time of any streamers or coloured haze in a $W$. by N. to N.E. direction, the sky being cloudless, perfectly clear, and the stars shining with their usual brightness. On the formation of the corona a sheet of fan-shaped sea-green haze shot from it in a $\mathrm{N}$. direction, spreading rapidly as it advanced, but did not proceed for more than $20^{\circ}$, when it suddenly disappeared. The streamers were remarkably steady throughout and straight, unlike those during the display of November ro of last year, which were wave-like, rapid, and flickering. By half-past seven the entire sky had assumed a greenish tinge, with a reddish glow in some places, and a few resplendent beams of white light from the E. chieffy. At a quarter to eight red streamers became visible in a $N$, direction, at a considerable elevation, resting on a greenish haze, itself emanating from a very indistinctly white arch spread across the $N$. At nine the sky was still tinged, and a streamer here and there visible, but by ten the display was over, as clouds had obscured the heavens. Although the red colours were so intense and deep, the stars could be distinctly seen through them, and when the streamers suddenly changed to white, \&c., it was possible to see the time on a watch, though the night under ordinary circumstances would have been dark. A common dipping needle which marked $56^{\circ}$ at noon changed to $45^{\circ}$ before the aurora became visible. Barometer corrected and reduced, 29748 . Temperature, $37^{\circ}$ at the time. Solar radiator during the day, $77^{\circ}$. A few shooting stars darted across the heavens in a south from east direction, mainly during the aurora, A wet night afterwards set in.

Blencowe School, Cumberland, Feb. 5 